\title{
PERAN ANALISIS DNA TERHADAP INFEKSI PARASIT NEUROSISTISERKOSIS
}

\author{
Muhammad Luthfi Al Manfaluthi*
}

Neurncvcticercosis is a infectious diseases caused bv T.solium lavvea. small amount of this shecies can make heavv conseauences even death.

\begin{abstract}
ABSTRAK
Neurosistiserkosis adalah penyakit infeksi yang disebabkan oleh bentuk. larva T.solium, meskipun dalam jumlab minimal infeksi ini mampu

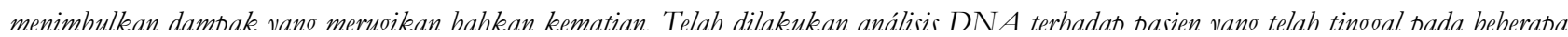

yang lalu saat berada di Nepal.

Penyakit cacing pita babi Taenia soliumadalah salah satu penyakit yang mendapat prioritas penanggulangan dikaitkan dengan derajat patogenesitasnya. Pada manusia, infeksi jenis parasit ini dibagi menjadi dua berdasar siklus hidupnya: (1) teniasis, infeksi oleh cacing dewasa yang disebabkan oleh konsumsi daging babi yang mengandung sistisekus (bentuk larva) dan (2) sistiserkosis, infeksi oleh stadium larva cacino nita vang disebabkan

cacing pita.

Neurosistiserkosis adalah infeksi bentuk larva parasit cacing pita babiyang menyerang susunan syaraf pusat. Infeksi ini sangat membahayakan dan sering terjadi tidak hanya dibeberapa negara berkembang tetapi juga pada negara maju dikarenakan peningkatan laju migrasi dan pariwisata bahkan pada negara-negara yang memberlakukan pelarangan mengkonsumsi daging babi (Ibrahim, 2003). Karenanva sanoat nentino untuk memastikan

pada daerah nonendemis (Ito, 2003).

Pada bulan agustus 1996, seorang warga jepang berumur 46 tahun mengeluhkan nyeri kepala bersifat tumpul selama perjalanannya di jakarta, dia

\footnotetext{
* Staff Pengajar di Fakultas Kedokteran

Universitas Muhammadiyah Malang
}

menjalani pemeriksaan kesehatan di rumah sakit di manila pada perjalanan kembali ke jepang. hasil CT-scan menunjukkan tumor pada lobus temporal bagian kiri. Kemudian dia dirawat dirumah sakit Kisato, observasi intensif menunjukkan lesi kistik tunggal dengan cincin perkabutan disekitarnya. Dia tidak mengalami ganguan syaraf yang lain dan hasil pemeriksaan darah dalam batas normal. Pada bulan september pasien menjalani operasi bedah otak dan ditemukan kapsul berdinding tipis berukuran 1 $\mathrm{cm}$. Pemeriksaan histopatologi mengungkap spesies T. solium (Yuzawa, 2003). Pasien mengalami pemulihan yang cepat dan dapat kembali berkerja setelah 19 hari setelah operasi. Neurosistiserkosis denoan kista tunogal akhirnva danat dinastikan

dari Universitas Asahikawa (Ito, 1999).

Dimanakah pasien terjangkit infeksi? karena jepang bukan termasuk daerah endemis teniasis/ sistiserkosis. Diasumsikan pasien terinfeksi parasit ini diluar jepang. Dia bekerja sebagai menejer teknis perusahaan internasional selama 12 tahun sejak 1970 dan telah mengunjungi Indonesia, Nigeria, Nepal, and Malaysia, dimana kasus neurosistiserkosis telah sering dilaporkan dari negara-negara tersebut (Murrell, 2005). Dikarenakan pasien telah tinggal di Indonesia selama 6 tahun sebelum onset penyakit (1990-1996), dicurigai pasien terkena infeksi di 
Indonesia. Untuk menyelesaikan misteri asal infeksi dilakukan analysis cytochrome $c$ oxidase I (cox1) denoan DNA mitokondria (mtDNA) menoounakan

paraffin hasil operasi sebelumnya.

Berdasarkan análisis filogenetik menggunakan sekuen mtDNA, $T$. soliumdiklasifikasikan menjadi 2 jenis genotipe yaitu: Asia dan Africa atau amerika latin (Nakao, 2002). Pemeriksaan histologis menggunakan xylene dan etanol untuk menghilangkan parafin kemudian direhidrasi sebelum ekstraksi DNA dengan set jaringan DNeasy(Qiagen, Germany). Dikarenakan terjadinya degradasi DNA, proses mengalami kesulitan untuk mendapatkan frogmen DNA panjang dari sediaan formalin, sehingga kami melanjutkan dengan PCR (polymerase chain reaction) menoounakan nrimer utama dan dinerkuat milai

\begin{tabular}{|c|c|c|c|}
\hline Primers & Sequence $\left(5^{\prime}\right.$ is 3 ) & Positions & Refienena \\
\hline Tol exal/Fon & azguttragtogere & $1-19$ & ps \\
\hline Tsol coxal/F100 & 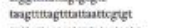 & $101-125$ & \\
\hline Tsol cosal/7180 & 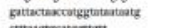 & $179-204$ & PS \\
\hline Tolol & 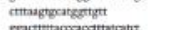 & $\begin{array}{l}305-323 \\
370\end{array}$ & ${ }_{p s}^{p s}$ \\
\hline Trot uxa $1 / 7380$ & 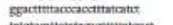 & $379-405$ & PS \\
\hline 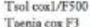 & 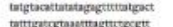 & $\begin{array}{l}497-525 \\
40955\end{array}$ & Ps \\
\hline 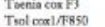 & 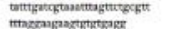 & $\begin{array}{l}629-556 \\
845-856\end{array}$ & ps \\
\hline 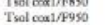 & 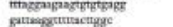 & $\begin{array}{l}846-866 \\
951-970\end{array}$ & $\begin{array}{c}\mathrm{PS} \\
\mathrm{PS}\end{array}$ \\
\hline 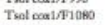 & 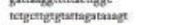 & $1078-1100$ & PS \\
\hline 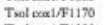 & magngmoxes' & $1175-1194$ & ps \\
\hline Troblocos1/F1290 & 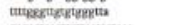 & $1293-1311$ & PS \\
\hline Tsol coni//F1420 & 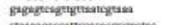 & $1421-1443$ & PS \\
\hline 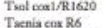 & 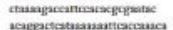 & $\begin{array}{l}1620-1594 \\
1007-1474\end{array}$ & PS \\
\hline 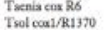 & 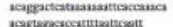 & $\begin{array}{l}1502-1474 \\
1070-1345\end{array}$ & Ps \\
\hline Tool $\cos 1 / \mathrm{R} 1280$ & 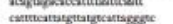 & $\begin{array}{l}1730-1343 \\
1282-1233\end{array}$ & $\begin{array}{l}\text { PS } \\
\text { PS }\end{array}$ \\
\hline Thol exa1/Ru1so & 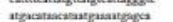 & $1150-1125$ & Ps \\
\hline Thol oca1/R1050 & 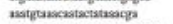 & $1053-1029$ & PS \\
\hline Tienia cos $\mathrm{R} 4$ & 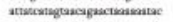 & $935-907$ & \\
\hline 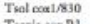 & 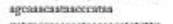 & 828-509 & Ps \\
\hline Tsxnis eus 83 & 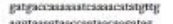 & $721-694$ & \\
\hline 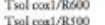 & 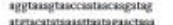 & $\begin{array}{l}600-573 \\
505-478\end{array}$ & ${ }_{\mathrm{PS}}^{\mathrm{PS}}$ \\
\hline 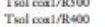 & 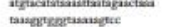 & $\begin{array}{l}505-78 \\
399-380\end{array}$ & Ps \\
\hline 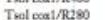 & 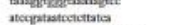 & $282-263$ & PS \\
\hline Tsol cosul/R190 & 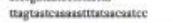 & $188-162$ & PS \\
\hline
\end{tabular}

Produk PCR diurutkan dan dibandingkan dengan sekuens cox1dari data base utama. Sekuens yang digunakan sebagai pembanding adalah : China 1 (AB066485), China 2 (AB066486), Korea (DQ089663), Thailand (AB066487), Papua (= sebelumnya bernama Irian Jaya) (AB066488), Bali (AB271234), India (AB066489), Mexico/Peru/ Cameroon (AB066490), Ecuador/Bolivia (AB066491), Brazil (AB066492), Tanzania/ Mozambique (AB066493). Karena sekuen cox 1 identik dengan nepal, dimana negara tersebut pernah pasien tinggali untuk supervisi perusahaan (19781979, 1984-1986), maka dilakukan pemeriksaan DNA sistisekus dari hewan babi pada 3 tempat berbeda di Nepal (Sunsari, Moranga, and Kathmandu) untuk analysis cox1. Diambil satu sistiserkus dari tiap-tiap lokasi dan dilakukan analisis seperti sebelumnya (Nakao, 2002). Hasilnya, didapatkan sekuen parsial cox1 (1570 bp) dari nasien (AB494702) dan kedua sekuen vano herheda

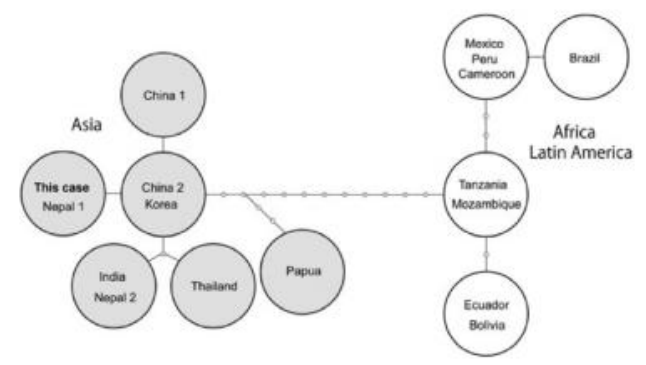
Figure 1 The statistical parsimony networks of corl $l$ haplotypes based on 1570 bp sequences. Circles represent haplotypes and
each node indisates one mutation step.

AB491985, Nepal 2: Moranga and Kathmandu, AB491986). Sekuen dari pasien sangat identik dengan salah satu dari dua haplotipe Nepal yang diperoleh dari daerah Sunsari. Untuk mengestimasikan hubungan genealogi diantara haplotipe didunia dilakukan analisis parsimony berdasarkan sekuen cox1 (1570 bp) dengan program tcs1.2 (Clemen, 2000). Hasilnya, haplotipe secara jelas dibagi menjadi 2 kelompok geografis sebagaimana sudah dilaporkan sebelumnya (Nakao 2002)dari pasien ini didapatkan basil berasal dari asia. Haplotipe dari bali Indonesia tidak disertakan pada analisis DNA dikarenakan sekuensnya terlalu pendek (1188 bp) pada bank genetik dunia dan secara jelas memang berbeda dengan kelompok yang lain. Hasil dari pemeriksaan DNA terahir menyimpulkan bahwa pasien memang tidak terinfeksi T. soliumdari indonesia tetapi dari Nepal, negara endemis sistiserkosis (Amatya, 1999). Hasil analisis DNA juga mengindikasikan pasien terpapar infeksi sebelum tahun 1986 pada kunjungan terahir ke Nenal dan hal ini herarti larva cacino tersebut

tahun.

Neurosisteserkosis adalah penyakit yang disebabkan oleh masuknya bentuk telur infektif $T$. solium yang kemudian akan menjadi bentuk larva dan menyebabkan gangguan padaorgan yang dilaluinya, meskipun hanya terinfeksi satu telur tapi dampak yang ditimbulkan sangat membahayakan bahkan kematian. Pengendalian dan pencegahan pada penyakit ini sangatlah penting, karenanya mengetahui dimana, bagaimana dan kapan pola pasien terinfeksi sangatlah penting terutama pada negara yang tidak endemis. Peran analisis DNA menggunakan gen cox1adalah alar ukur yang sangat specific dan sensitif untuk mendeteksi kasus serupa 
terutama dengan latar belakang pasien yang selalu berpindah-pindah. Pada pasien ini kita dapat dibiaskan antara neoara endemis dan non-endemis

\section{Daftar Pustaka}

Amatva BM. Kimula Y. Sistiserkosis in Nenal: a

Am J Surg Pathol 1999; 23:1276-1279.

Clement M. Posada D Crandall KA. TC.S: a

genealogies. Mol Ecol. 2000; 9:1657-1659.

Ibrahim N. Azman Ali R. Basri H. et al.

Neurol J Southeast Asia 2003; 8:45-48.

Ito A. Nakao M. Wandra T. Human taeniasis and

1920.

Ito A, Nakao M, Ito Y, et al. Neurosistiserkosis case with a single cyst in the brain showing dramatic dron in snecific antibodv titers

Parasitol Int 1999; 48:95-99

Murrell KD. Epidemiology of taeniasis and sistiserkosis. In: MurrellKD ed. WHO/FAO/ OIfGuidelines for the surveillance.

sistiserkosis. Paris: OIE, 2005:27-43.

Nakao M, Okamoto M, Sako Y, et al. A phylogenetic hypothesis for the distribution of twogenotvnes of the nig taneworm

124:657-662

Yamasaki H, Nakao M, Sako Y, et al. Molecular identification of Taenia solium cysticercus genotvne in the histonatholnoical snecimens.

2005; 36(Suppl):S131-S134.

Yuzawa I. Kawano N Suzuki S et al. A case of 2000; 9:364-369. 